\title{
Yazınsal Bir Gençlik Edebiyatı Metni Olarak The Catcher in the Rye/Çavdar Tarlasında Çocuklar'ın Analizi ve Çevirmenin Görünmezliği Üzerine Küçük Bir Yolculuk
}

\author{
The Catcher in the Rye and its Turkish Translation as a Young-Adult Novel: A Micro- \\ Scale Journey into Translation Analysis and Translator's Invisibility
}

Araştırma/Research

\author{
Necdet NEYDiM* \\ *Doç. Dr., İstanbul Üniversitesi, Edebiyat Fakültesi, Çeviribilim Bölümü, Almanca Mütercim-Tercümanlık \\ Anabilim Dalı, neydim@istanbul.edu.tr, ORCID ID: https://orcid.org/0000-0002-5708-6496
}

\section{ÖZET}

The Catcher in the Rye/Çavdar Tarlasında Çocuklar Amerikalı yazar Jerome David Salinger'in 1951 yılında basılmış romanıdır. Kitap, yayınlandığı döneme ciddi etkiler yaptığı gibi, hedef kitlesinde de unutulmaz izler bırakmıştır. Birçok dünya diline çevrilen metin, bir ergen romanı olarak ana kahramanının hayata dönük duruşunda olduğu gibi hep muhalif olmuş metnin ana eksenini oluşturan düşünceye baktığımızda bu kahraman hiç olgunlaşmak istememiş ve hayata katılmayı reddetmiştir. Dönemine bakıldığında ideal mükemmel çocuk anlayışı gereğince yatılı okula iyi bir eğitim alması için gönderilen Holden, okul hayatında ve dış dünyada asla uyum sağlayamayacağı insanlarla karşılaşmış; ergenliğin zirve noktasında dolaşan Holden'in bu uyumsuzluğunu yazar, aynı zamanda ergenin başkaldırıcı ruhunu da kullanarak dönemimin anlayışlarıyla ciddi biçimde hesaplaşmıştır. Bu nedenle yayınlandığı dönemde defalarca yasaklanmış ve okullara girişi engellenmiştir. Bütün bunlardan yola çıktığımızda kitabın farklı ülkelerde çevirisi ve alımlamasının önem kazandığını düşünebiliriz. Kitap Türkçeye iki farklı dilden çevrilmiştir. Fransızca (ikinci dilden Adnan Benk) ve İngilizce (kaynak dilden Coşkun Yerli). Çalışmamızda çeviri karşılaştırması yapmaktan daha çok, verilen kararların çevirmeni görünür yapıp yapmadığı ve bunun ölçütü konusunda kuramsal çerçevede düşünce yolculuğu yapmak ve başka araştırmalarda bu konu nasıl ele alınırın ip uçlarını yakalamak ana hedefimizi oluşturmaktadır. 
Anahtar Sözcükler: ergen romanı, ergen dili, ergen romanı çevirisi, çeviri yaklaşımları, çevirmenin görünmezliği

\begin{abstract}
"The Catcher in the Rye" is a young-adult novel by American writer Jerome David Salinger, which was published in 1951. The book had a significant impact on the period it was published and also left unforgettable traces in its target audience. Having translated into various languages, this young-adult fiction shares its opposing aspects with those of its protagonist's life stance. The main axis of this dissident novel is comprised of the idea that the protagonist never wants to mature and refuses to participate in daily life. After being sent to a boarding school for a decent education, which is perfectly in accord with the construction of the ideal child in that era, Holden encounters people with whom he would never get along both at and outside of school. The writer uses the discordance of Holden, a complete teenager, together with his rebellious soul, and therefore, keenly confronts the understandings of the era in question. Due to its dissident character, it is repeatedly banned after its publication and not allowed to be in schools. Depending on current perception of reality, it is safely recognized that translations and reception of this novel in different languages gain prominence. The novel is translated from two different languages into Turkish: one is French language used by Adnan Benk, which is a relay translation, and the other is English -source- language used by Coşkun Yerli. This study deals with the question as to whether the translation decisions make the translator visible by considering its implications for the theoretical discussions rather than directly comparing those two translated novels. Our main goal is to shed light on tracing the clues of how to deal with this issue in other studies.
\end{abstract}

Keywords: young-adult novel, young-adult language, translation of young-adult novel, approaches to translation, translator's invisibility

\title{
1. Giriş
}

Çavdar Tarlasında Çocuklar (özgün adıyla The Catcher in the Rye), Amerikalı yazar Jerome David Salinger'in 1951 yılında basılmış romanıdır. Times Dergisi ve okuyucular tarafından İngiliz dilinde yayımlanmış 20. yüzyılın en iyi yüz eseri arasında olan Çavdar Tarlasında Çocuklar (kısaltma ile: ÇTÇ) günümüzde hâlen birçok kişi tarafından "20. Yüzyıl modern edebiyatının başyapıtı" olarak değerlendirilmektedir. "Ahlâk dışılığı" ve "sakınmasız dili" ve üslubu ile dünyada ve özellikle Amerika'da ergen edebiyatı bağlamında bir dönem yasaklanan ve aynı zamanda da en fazla okurla buluşabilen bir kitaptır. 1967'de Adnan Benk'in Fransızcadan yaptığı çeviriyle Türkiye'de Gönülçelen adıyla tanındı. Kitap daha sonra YKY tarafından yayımlandı ama bu kez metni kaynak dilden (İngilizce) Coşkun Yerli çevirdi. Kitapta, başkahramanı Holden Caulfield'ın ağzından, okuldan atılmasıyla başlayan üç günlük süreç anlatılır. Çavdar Tarlasında Çocuklar 20. yüzyılın tam ortasında oluşmuş bir eserdir. Eser hakkında yorum yapmadan evvel sadece kitap içi etmenlerin değil, o günkü dünya konjonktürünün de kısa bir analizinin ve aktarımının, değerlendirme açısından büyük bir katkısı olacağına inanıyorum. Bu sebeple, öncelikle kitabın içinde oluştuğu yüzyıla ve edebi akımlara kısaca değinmek istiyorum. Ardından Türkçeye yapılan çevirilerde çevirmen kararları, 
Yazınsal bir Gençlik Edebiyatı Metni Olarak The Catcher in the Rhy/Çavdar Tarlasında Çocuklar'ın Analizi ve Çevirmenin Görünmezliği Üzerine Küçük Bir Yolculuk

onları etkileyen faktörler, bu süreçte çevirmenin görünürlüğü ya da görünmezliğine dönük sorgulamalar yer alacaktır. Metnin ergen edebiyatından önemli bir örnek oluşu, dili (gençlik dili), metnin oluşumuna baktığımızda kendine özgülüğü ve öncü ergen edebiyatı örneği oluşu çeviri yaklaşımları ve bunda çevirmenin verdiği kararlar incelemede özellikle göz önünde tutulacaktır.

\section{2. Çavdar Tarlasında Çocuklar ve Yazınsal Dönem}

19. yüzyılın sonunda edebiyatta doğalcılık ve temelleri 19. yüzyılın ikinci çeyreğinden sonra atılan ve 20. yüzyılın başında hâlen hissedilen gerçekçilik akımları görülür. 20. yüzyılın başındaki gerçekçilik akımları ile özellikle Amerika'da ürünlerini vermiş olan Büyük Bunalım Dönemi eserlerinden sonra, 2. Dünya Savaşı́nın da etkisiyle "Amerikan Rüyası"na düşen gölgeler, insanları gerçek hayatta olduğu gibi edebiyatta da hayatın anlamını ve bireyselliği, toplum sonrası bireyin problemlerini varoluşçu bir gözle sorgulamaya itmiştir. Toplum ve birey, bir yandan Sanayi Devrimi ile uzun bir süre önce hayatlarına girmiş olan verimlilik ve seri üretim fikirleri ile bir ideale yaklaşma çabasında kendisini farklı kalıplara sokarak "belirsiz idealine" yaklaşmaya çalışırken, iktidar ve güç peşinde kaybedilen savaşlarla kendi varoluşunu ve bunun temelinde yatan değerleri sorgulamaya başlamıştır.

Özellikle II. Dünya Savaşı, Amerikan toplumunun yerleşmiş değerlerinin yeniden gözden geçirilmesine yol açmıştır. Savaşın anlamsızlığı ve yol açtığı bunalımlar yeni yazarlar için esin kaynağı olurlar. 1950'lerin ve 1960'ların Amerikan edebiyatı içinde Yahudi kültüründen ve mizahından kaynaklanan çok sayıda kitap göze çarpar. Eleştirmenlerin ilgisini çeken yapıtlar arasında Ralph Ellison'un, insanlık onuruna verdiği önemi vurgulayan Görünmeyen Adam'ı (Invisible Man, 1952); James Bakhvin'in insan hakları hareketini destekleyen yapıtları ile Beat Kuşağı'nın babası Jack Kerouac'ın, yoksulluk ve özgürlüğü kutsadığı Yolda (On the Road, 1957) romanı; çağdaş kent yaşamını anlatan Nelson Al-gren'in Altın Kollu Adam'ı (The Man with Golden Arm, 1956) bulunur. Bu eserler konularıyla 20. yüzyıl yaşam tarzını sorgulayan eserlerdir. Yayımlanmış savaş romanlarının yanı sıra Joseph Heller'in Şike'si (Catch, 1961) askeri bürokrasinin anlamsızlığına dikkati çeker. Ken Kesey'nin Guguk Kuşu toplumun akıl hastalarına karşı tutumunu eleştirir. Truman Capote gerçek kesitten tiyatro oyunu niteliğinde öyküler ve romanlar yazar. Protagonist Holden Caulfield'in en sevdiği kitaplardan biri olduğunu vurguladığı Muhteşem Gatsby (The Great Gatsby, 1925) de Amerikan Rüyası'na yöneltilmiş bir eleştiridir.

Bu noktada yazar J. D. Salinger ise Çavdar Tarlasında Çocuklar (The Catcher in the Rye, 1951) ile eğitim sistemine ve topluma olan tepkisini ortaya koyar. Hayata olan alaycı yaklaşımıyla kitabın kahramanı genç Holden Caulfield, amaçsızlığı, yaşadığı yabancılaşmayı ifade tarzındaki açık saçıklık ve hayata sövmesiyle farklı jenerasyonlara hitap etmeyi başaran bir anti-kahramandır. Kitabın ana karakterinin sıradışılığı, kendisini takip eden Beat Kuşağı (Beat Generation) döneminin habercisi gibidir. Beat Kuşağı 
1950'lerde ABD'de ortaya çıkan popüler kültür karşıtı yazarları tanımlamak için kullanılan bir terimdir. Bu kuşağı temsil eden eserlerin ortak noktaları o dönemde uyumsalcı (konformist) bir yaşamı üstün kılan Amerikan toplumunun bu değerlerine karşı olmalarıdır. ÇTÇ yayımlandığı sırada Amerika'da gelişen endüstriyel ekonomiyle zenginleşmeye başlayan toplum ve sıkılaşan sosyal kurallar, gençliği uyum sağlamakla görevlendirdiği bir kalıba yönlendirmiştir. Kültürel karşı-devrimin 1950'lerde oluşum sürecinde ÇTÇ, okur tarafından kalpsiz ve sıkı kuralları olan bir dünyada bireyin yabancılaşmasının öyküsü olarak benimsenir. Holden birçok okuyucu için kültürel baskının öbeğinde kısıtlanamayacak saf bireyselliğin sembolü hâline gelir. Özetle, ÇTÇ'nin oluşum sürecinin öncesinde toplumu sorgulamaya iten sosyolojik ve politik olaylar (1. ve 2. Dünya Savaşları, Büyük Bunalım) ve "Amerikan Rüyası", sonrasında ise Amerikan Rüyası'ndan uyanış, "beatik" ve hippi yaşam tarzları bulunmaktadır. Bu çerçeve içinde eser bir dönüm noktasında durmuş, bu noktada sergilediği duruşla fark yaratmış, bu yüzden de ileriki yarı yüzyılda güncelliğini ve popülerliğini sürdürebilmiştir.

\section{3. Çavdar Tarlasında Çocuklar ve Yazınsal Tür Olarak Yeri}

Eleştirmenlerce konu bakımından oluşum romanı (bildungsroman) olarak sınıflandırılan ÇTÇ, gerçekçi üslubuyla birinci şahıs tarafından anlatılan bir romandır. 1950'li yılların Amerikan gençliğinin kullandığı argo ve gündelik dille yazılmış olan eser, kahramanı Holden Caulfield'in sözde otobiyografik öyküsünü ele alır. Yirmi altı bölümden oluşan kitapta, her bölüm kendi başına bir öykü özelliği taşırken, bütününden bir kopukluk oluşturmaz. Olay örgüsü sadedir.

Oluşum romanları tür itibarıyla bir olgunlaşma sürecini konu alırlar. Bu tür romanların tipik özellikleri; protagonistin gençlikten yetişkinliğe geçtiği bir dönemde olması, bir kayıp veya değişiklik yüzünden içinde bulunduğu ortamdan kopması ve kopuş sonrası süreçte olgunlaşmasıdır. Olgunlaşma süreci kahramanın ihtiyaç ve isteklerinin sosyal düzenin resmi ve tavize kapalı yargıları ve bakış açısı ile düzenli olarak çarpışarak şekil aldığı, uzun, zorlu ve kademeli bir süreçtir. Fakat bu sürecin sonunda sosyal düzenin ilerleyişi kahraman perspektifinden anlaşılır ve aşikâr bir hâl alır. Kahraman bu sayede topluma yeni bir noktadan dâhil olur. Pikaresk romanların aksine roman kahramanı, olaylar ve ilişkiler içinde değişir, dönüşür ve bütünlenir. Bu kriterlere bakarak ÇTÇ’yi değerlendirecek olursak eser, Holden Caulfield'in kardeşi Allie için tutamadığı, olanaksız kılınan ya da reddedilen matemin sıra dışı bir incelemesidir ve bir oluşum romanıdır. Matemi yüzünden toplumun değer yargılarına isyan etmeye başlayan Holden, kardeşi Allie ile özdeşleştirdiği samimiyet, dürüstlük ve masumiyet kavramlarını toplum ve bireylerin içinde yaşatmaya ve bu değerlerin savunucusu olmaya çalışsa da, kitabın sonunda her bireyin "düşüşler" yaşayabileceğini, acı deneyimlerin de kendi özünde bir eğiticiliği olduğunu anlar, karakteri değişmese de hayata bakışı değişir ve isyanına son verir. 


\section{Başlık Analizi}

Robert Burns - "Comin' Through The Rye" (Çavdarlar Arasında)

"Comin' Through the Rye" şiiri Salinger'ın metaforik kitap başlığının (The Catcher in the Rye) çıkış noktasıdır. Bir İskoç şairi olan Robert Burns'ün bu şiiri, daha sonra bestelenerek bir çocuk şarkısı olmuştur. Holden yolda yürürken bu şarkıyı söyleyen bir çocuk görür ve çocuğun neşeli, umarsız tavrı çok hoşuna gider. Fakat şarkının sözlerini yanlış duyar. "Gin a body meet a body/ comin' through the rye", yani, "Rastlarsa birine biri, çavdarlar arasında" mısrasını "Gin a body catch a body/ comin through the rye", yani ,"yakalarsa birini biri, çavdarlar arasında" olarak duyar. Başlığın ne olacağı sorulduğunda Robert Burns'un bir şiirinden bir alıntı yaparken hata yapar ve "the catcher in the rye" (çavdar tarlasındaki tutucu/ yakalayıcı) der. Burns'un şarkısı "Comin' Thro' the Rye" günümüzde farklı versiyonlara sahiptir. Her versiyonda şarkı sözleri farklılıklar taşır. Bazılarında şarkı çavdar tarlasında yere uzandığı için eteği ıslanan bir kadını anlatır. Diğerlerinde ise çavdar tarlasında olmayı sorgulayan bir kadını konu alır. Ama hepsinin ortak bir noktası vardır: "Çavdar tarlasında karşılaştığın birini selamlamak ve öpmek yanlış mıdır, hele de o kişiyle ciddi bir ilişkin yoksa? Bunu tüm dünya bilmek zorunda mıdır?" Şarkı bu noktada açık bir şekilde cinselliğin sıradanlaşmasını sorgulamaktadır. Holden'ın hikâyesinde de rahatsız edici bir şekilde yansır. Holden düşlerinde masumiyetin tek koruyucusu olan beyaz şövalyenin çağdaş versiyonudur. Kocaman bir çavdar tarlası hayal eder ve çavdarlar o kadar uzundur ki oyun oynayan küçük çocuklar koşarken yönlerini saptamaktan acizdirler. $O$ ise tarladaki tek yetişkindir. Yapması gereken o çocukların uçurumdan aşağı düşmemeleri için kenara yaklaşanları yakalamaktır. Uçurumdan düşmek demek çocukluğun ve özellikle cinsel masumiyetin kaybı demektir. Dönemi etkileyen ana motif olarak geçerlidir bu durum. İçerdiği anlam da çocukları uçurumdan düşerken yakalamak, bu bağlamda onları cinselliğe adım atacakları ergenlikten korumaya çalışmaktır.

\section{5. Çavdar Tarlasında Çocuklar’a Genel Bir Bakış}

Holden Caulfield, hikâyesini terapi için gönderildiği bir sanatoryumdan anlatır. Hikâyenin başında çocukluğundan ve hayatından genel olarak bahsetmek istemediğini belirtir. Amacının bir yıl önce yılbaşı arifesinde başına gelenleri anlatmak olduğunu söylerken, ağabeyi D.B. den bahseder. D.B. Kırmızı Balığın Esrarı adında Holden'ın çok sevdiği bir kitabın yazarıdır. Fakat daha iyi para kazanıldığı için Hollywood'da senaryo yazarlığı yapmaktadır. Bu durum Holden'ın hiç de olumlamadığı bir durumdur. Bunlardan bahsettikten sonra Holden Pencey Hazırlık Okulu'ndan atılışından başlayarak geçirdiği sinir krizini anlatır. Pencey Hazırlık, Pensilvanya Eyaleti'nde Agerstown şehrinde bulunan kalitesiyle ünlenmiş bir okuldur. Holden, eğitim hayatını okula bir sonraki dönem için başvurmayarak ve aldığı beş dersten İngilizce dışında dördünden kalarak zora 
sokmuştur. Sonuç olarak Noel tatili arifesinde okuldan atıldığı haberini alır ve artık tatilden sonra okula dönemeyecektir.

\section{6. İçerik Analizi}

\subsection{Zaman ve Mekân}

Kullanılan zaman da bu tabloya uygun olarak giriş sayfası ve son bölüm dışında di'li geçmiş zamandır. Mekân genel olarak Pencey ve New York olsa da, Holden her bölümde birçok kez mekân değiştirir.

Hikâyenin Çerçevesi: Holden'ın Şimdiki Zamanı (1950)

Giriş, Başlangıç, California, Sanatoryum, Holden'ın Geçmişi: Anılara Geri Dönüş, (1949, Noel Arifesi), Bölüm 1 - 14, Bölüm 15 - 24, Bölüm 25, PENCEY => New York New York New York, Cumartesi Pazar Pazartesi, Bölüm 26, California, Sanatoryum

Olayların 1940'ların sonu 1950'lerin başı civarında yaşandığı çok belirgindir. Yazıldığı döneme bakıldığında bu döneme ilişkin veri çoktur. Allie'nin ölüm tarihi 18 Temmuz 1946 olarak belirtilir. O sıralarda Holden on üç yaşındadır. Kitap son bölümde 1950'lerden bahseder.

\subsection{Karakterler}

Holden Caulfield: Olaylar 16 yaşındaki Holden'ın gözünden anlatılmaktadır. Öykünün kahramanı Holden başarısızlıkları sebebiyle okuldan atılır. Zeki ve duyarlı bir genç olan Holden'ın alaycı tarzı tüm roman boyunca dikkat çeken bir unsurdur. Yetişkinlerin kurduğu sosyal düzenin "sahtekârlığından" tiksinmektedir. Karakterinin zayıf yanlarının farkında olmakla beraber, bunları değiştirmek için hiçbir şey yapmaz ve öyküde anlatılan her birey kadar sahtekâr davranmaktadır.

Phoebe Caulfield: Küçük kız kardeş. Masumiyeti temsil ediyor.

Allie Caulfield: Ölen erkek kardeşi.

D. B. Caulfield: Ağabeyidir. Senaryo yazarıdır. Ünlüdür.

Robert Ackley: Okul yurdundaki oda arkadaşı.

Jane Gallagher: Metinde görünür değildir; ama Holden'in tutku duyduğu söylenebilir.

Ward Stradlater: Yakışıklı ve popüler oda arkadaşı. Cinsellik deneyim özeldir.

Bay Spencer: Tarih öğretmeni.

Bay Antolini: Eski İngilizce hocası.

Carl Luce: Eski okuldan arkadaşı.

Sally Hayes: Çıkma teklifi ettiği kız.

Maurice: Edmont Oteli'ndeki asansörcü çocuk. Kadın pazarlamacısı. 
Sunny: Genç bir hayat kadını.

Ossenberger: Pencey'den mezun olmuş zengin bir iş adamı.

Ernest Morrow: Annesine hakkında çok duyarlı biri olduğunu söylerken; okura, tanıdığı en büyük sahtekârlardan biri olduğundan bahsettiği çocuk.

Valencia: Valencia, The Wicker Bar'daki kadın.

Faith Cavendish: Holden'ın New York City'de canı sıkılıyorken telefonla aradığı kadın.

Ernie: Ernie New York'ta bir barda piyano çalan kişi. Ernie'nin oldukça yetenekli olduğunu düşünen Holden bir yandan onu "yapmacık"lıkla suçlar.

Horwitz: Holden'ın bindiği taksinin şoförü.

Lillian Simmons: Caulfield'ın eski arkadaşıdır. Barda yeniden karşılaşmıştır.

Jim Steele: Holden'ın uydurduğu başka bir kimlik.

James Castle: Whooton'dayken intihar eden çocuk.

Dr. Thurmer: Pencey Prep'in müdürü.

Selma Thurmer: Pencey Prep'in müdürünün kızı. Aralarında bir kerelik diyalog geçmiştir.

\subsection{Tema, Semboller ve Motifler}

\subsubsection{Temalar}

\subsubsection{Kendini Koruma Yöntemi Olarak Yabancılaşma}

Roman boyunca Holden kendini dünya tarafından dışlanmış ve bu sahtekâr sosyal düzenin kurbanı olan bir insan olarak ifade eder. Hayatın çok da eğlenceli olmayan "öbür tarafında" kapana kısılmış hissetmektedir ve ait olmadığı bu evrenden bir çıkış yolu aramaktadır. Hikâyenin ileri bölümlerinde, bu yabancılaşmayı yer yer uyum sağlamak zorunda kalmamak, bazen de gerçeklerle yüzleşmekten korunmak için bir silah olarak kullandığını görürüz.

\subsubsection{Olgunlaşmanın Acısı ve Ağırlığı}

Olgunlaşmaya ve büyümeye karşı koymaya çalışan Holden'ın bu kaçışının sebebi, değişimden korkmasıdır. Çünkü kardeşi Allie'nin ölümüne sebebiyet veren şey de hayatın değişkenliğinin ta kendisidir. Fakat insan, kendi içinde de değişken bir varlıktır ve değişimden kaçarken Holden farkında olmadan değişir. Hayatın gerçekleriyle yüzleşirken onları inkâr etmekten ziyade anlamaya çalışmayı öğrenir.

\subsubsection{Yetişkinler Dünyasının Sahtekârlığı}

"Sahtekâr" kelimesi bu romanda muhtemelen en fazla kullanılan kelimedir ve Holden'ın en sevdiği kavramdır. Holden bu kavramı belirli bir role bürünmeye çalışan veya toplumun kendisine uygun gördüğü rolü itiraz etmeden oynayan, samimiyetten ve 
dürüstlükten uzak bireylere, gerçekçi olmayan beklentilerin yalan tavırlarla tatmin edilmeye çalışıldığı yetişkinlerin dünyasına bir eleştiri ihtiyacı ile keşfetmiştir ve bu şekilde yönlendirir. Bu betimleme ile onlarla içten içe nasıl alay ettiğini belirtmeye çalışmaktadır. Onların yanındaymış gibi gözükse de aslında onlara "yabancı" olduğunu ifade etmek ister. Bir yandan kendisi de söylediği yalanlarla, gerektiği zaman oyunu onların kurallarıyla oynayabileceğini kanıtlamak istemektedir.

\subsubsection{Motifler}

\subsubsection{Yalnızlık}

Holden'ın yalnızlığı, yabancılaşmasının manifestosudur. Yalnızdır, çünkü onlardan değildir. Fakat bu yalnızlık onun umutsuzca anlamsız ilişkilerle ve tanışıklıklarla kendini bu dünyada tutmaya sebebiyet verecek bir bağ kurmaya çalışmasına neden olur.

\subsubsection{Ilişkiler, Yakınlık ve Cinsellik}

ilişkiler, samimiyet ve cinsellik roman boyunca tekrarlanan motiflerdir. Hem fiziksel hem de ruhsal paylaşım vurgulanmaktadır. Çünkü bu ihtiyaçlar Holden'ın kendini izole ettiği kabuğunu kırmaya iterler.

\subsubsection{Yalan ve Kandırma}

"Sahtekârlıklar" arasında en ağır ve yaralayıcı olanları yalan ve kandırmadır Holden'a göre. Fakat buna rağmen en büyük yalanları kendisi söylemektedir. Bu şekilde hayatın akışındaki değişimlerde eleştirdiği sahtekârlar kadar sorumlu ve suçlu olduğunu kanıtlamaya çalışmaktadır. Yaşamın devinimi içerisinde kendisinin de kontrolü ve etkisi olduğunu hissetmek istemektedir.

\subsubsection{Semboller}

\subsubsection{1. Çavdar Tarlasındaki Yakalayı ı}

Çocukları yanlışlardan ve sahte dünyaya alışarak değişmelerinden korumaya çalışan figür, Holden'ın hayalindeki meslek.

\subsubsection{Kırmızı Avcı Şapkası}

Holden'ın bireyselliğinin ve benzersizliğinin sembolü. Onun diğerlerinden farklı olma isteğinin ifadesi.

\subsubsection{Müze}

Holden için değişen dünyada değişmeyen tek gerçeklik. Bu yüzden kendini en rahat hissettiği yer. 


\subsubsection{Central Park'taki Ördekler}

Holden'ın kışın ördeklerin nereye gittiğini sorgulaması ve bu konudaki sönmeyen merakı, onun mızmız, söylenen ve yorgun karakterinin aslında sadece meraklı ve kızgın bir çocuk olduğunu hatırlamamıza yardımcı olan sembol olarak karşımıza çıkmaktadır.

\subsection{Dil ve Biçem}

Kitabın en dikkat çeken yanı dili ve biçemidir. Basıldığı yıllarda içerdiği "gençlik dili" (argo olarak tanımlanmış) yüzünden çok eleştirilen kitap, serbest düşünce akışı tarzındaki rahat anlaşılabilir ve birbirine bağlı olmayan ifadeleri ile birçok eleştirmen tarafından bunun bir sanat olmadığı yönünde eleştirilmiştir. 1950'lerin Amerikan gençliğinin jargonunu yansıtan eserde yazar, Holden'ın huysuz ve kızgın tavırları göz önüne alındığında karakteri tamamlayan bir unsur olarak dili kullanır.

ençlik dilinin çeviriye aynen yansıdığını söylemek doğru bir saptama olmaz. íki çevirmen de gençlik dili konusunda çekinik durmuşlar ve Benk Fransızcadan çevirirken o dilin çeviri yaklaşımına bağlı kalmasının yanı sıra kendi yaratıcıı̆̆ını da kullanmış ama gençlik dilini kullanmak yerine daha naif (yazınsal) yaklaşımlı bir metin oluşturmuştur. Yerli ise metnin dilinin argo olmadığını söylemiş ve bu öngörü ile metne yaklaşmıştır. Bütün bunların metne kazandırdığı ya da kaybettirdikleri başka bir araştırmanın konusu olarak düşünülmektedir.

\subsection{Yazar ve Baş Kahramanı Arasındaki Paralellikler}

Salinger, Valley Forge Military Academy'de okumuş ve bu okula kitabında Pencey adını vermiştir. Daha sonra Ursinus Fakültesi'nde bir dönem okuyan Salinger, hocaları tarafından okul tarihinin en tembel öğrencilerinden biri olarak tanımlanmıştır. Sosyal kaçışını inzivaya çekilerek göstermiştir. Kendisiyle ilgili yayınları hukuki yollarla engellemeye çalışmıştır. Bu süreçte ailesiyle olan bağlarını da koparmıştır. Çavdar Tarlasında Çocuklar'da da bu kaçışına ilişkin izler bulunur.

\subsubsection{Holden Caulfield İsim Analizi}

Caul, doğum sırasında yırtılması gereken amniyon kesesinin, yırtılmayıp çocuğun başı çevresinde varlığını devam ettirmesi sonucu çocuğun başı etrafında duran ve uğur getirdiğine inanılan zara verilen addır. Bu zar ile doğan çocuklar "caulbearer" yani, "zar taşıyıcısı" olarak adlandırılırlar. "Field" kelimesinin Ingilizcede tarla, çayır veya saha anlamına geldiği düşünülürse "Çavdar Tarlasında Çocuklar" fikri "Caulfield" soyadı ile kesinlikle anlamsal bir paralellik taşımaktadır. Anlam olarak doğum anındaki masumiyeti ömrü boyunca taşıyan bir kişiyi anlatır.

\subsubsection{Atlıkarınca ve Altın Çember}

Geçen yüzyılda atlıkarıncaların ortasındaki sütunda gümüş ve altın renklerinde çemberler takılı olurmuş. Atlıkarıncaya bindikleri sırada eğilerek altın çemberi yakalamayı başaran çocuklar bir tur bedava binme hakkı kazanırlarmış. Fakat altın 
çemberi yakalamaya çalışırken düşüp kendisini yaralayan çok fazla çocuk olması sebebiyle bu gelenek daha sonradan kaldırılmış. 25. bölümde Phoebe altın çemberi yakalamaya çalışırken Holden'ın korkmasının sebebi de bu çemberin çok uzakta durması ve Phoebe'nin düşme ihtimalinin yakalama ihtimalinden daha yüksek olmasıdır. Kültürel bağlamda bakıldığında çevirmenin bu tür verileri iyi incelemesi gerekir.

\section{Gençlik Dünyası ve Alt-Kültür Kavramı}

Gençliğin yazınından söz edecek olursak onun kendini anlatabildiği bir yazın türünden söz ediyoruz demektir. Ergen romanlarına baktığımızda bu metinlerin çoğunun içerden bir anlatımla oluştuğunu ve bir alt kültürü temsil ettiğini görürüz. Bu gençlik alt kültürlerinin tepki oluşturmak üzere nasıl ortaya çıktığını açıklayabilir. Onun duygularına seslenmeyen toplum yapısı, eğitim sistemi, aile içi ilişkiler bunun oluşumunu tetikler.

Bell, alt kültürlerin birer sistem olarak ortaya çıktığını, parasal, eğitsel, sistemsel bağlamda sınıflandırılmış ve sınırlandırılmış olduklarını çünkü henüz üretime katılmamış bir katmandan söz edildiğini söyler. Genç yine de bu süreçte kendi göstergelerini (moda, müzik, grup sembolleri) oluşturur ve dışa vurur (Krş. Asutay, 2001, ss. 2-3).

Ergenlerin (lise öğrencileri) alt kültürlerini okul dışı alanlarda ve okul dışı boş zamanlarda oluşturduğu ve tüm bunların tatil zamanlarıyla sınırlı olduğu gerçeği de söz konusudur. Öğrencilerin alt-kültürleri ise, daha çok okul dışı boş zamanlarında akşamları, hafta sonları veya tatillerle sınırlıdır. Aslında tüm bu süreç olgunlaşma ve yetişkin olma çabasıdır (Akt. Asutay, 2001).

\section{Gençliğin Dili}

Gençliği yetişkinden ayıran en önemli yanlardan biri ona özgü bir dilin varlığıdır. İşte yetişkinler dünyasının anlama konusunda zorluk çektiği ve reddettiği bu dil gençlik dilidir ve dönemsel bağlamda onun için çok önemlidir. Gençliğin dili, kültürü, davranış biçimleri yetişkinlerce reddedildiği için bu süreç yetişkinler dünyasınca baskı altında tutulmuş ve genç yetiştirilmesi gereken eğitilmesi zorunlu varlıklar olarak belirlenmiştir (Asutay, 2001, ss. 2-3).

Tüm bunlar gençlik edebiyatında kullanılan dilin argo dil (argo da güzeldir) aşağılanmasına, metinlerin sorgulanmasına trivial (harcıâlem) edebiyat olarak damgalanmasına neden olmuştur. Bu nedenle çevirmenler metnin saygınlığını artırmak için metne farklı yaklaşmışlar ve metnin dilini daha naif hale getirerek estetik değerini artırdıklarını düşünmüşlerdir.

\section{Bir Çeviri Kitap Olarak Çavdar Tarlasında Çocuklar/The Catcher in the Rye ve Çevirmenin Görünmezliği Üzerine}

\subsection{Gönülçelen ve Çevirinin Eşdeğerliliği}

Kitabın ilk çevirisi 1967 yılında Adnan Benk tarafından yapılmıştır. İlk çeviride Gönülçelen ismiyle satışa sunulan kitap, daha sonra 1997'de Coşkun Yerli (1950 - 2007) tarafından 
çevrildiğinde Çavdar Tarlasında Çocuklar ismiyle yayımlanmıştır. Kitabın başlığının esinlenildiği "Comin' Through the Rye" şiirini esas alarak, bu şiirin Holden tarafından yanlış duyulan "if a body catch a body coming through the rye" mısrasını "bir gönül bir gönlü çelerse, çavdarların arasında" diye çeviren Adnan Benk, kitabın adını da Gönülçelen olarak Türkçeleştirmiştir. Bu çevirinin doğruluğu tartışılsa da, "Gönülçelen" kelimesinin eleştirmenlerce Türk yazın dünyasında yaratılmış etkili imgeler arasında sayılmasını sağlar.

Öte yandan Sevin Okyay ve Coşkun Yerli, Holden'ın kendisini çavdar tarlasında oynayan çocuklar arasındaki yegâne erişkin olarak gördüğü hayalini esas alarak "catch" yani "yakalama" meselesini arka plana iterek Çavdar Tarlasında Çocuklar isminde karar kılmışlardır. Kitabın bütünü, kaybolan masumiyete bir ağıt olmakla, Gönülçelen gibi markalaşma potansiyeli taşımasa da Çavdar Tarlasında Çocuklar'ın meseleyi güzel yansıtan bir imge olduğu söylenebilir.

Tüm bunların kaynağı olan "catch a body" terimi ise, Amerikan argosunda, bir insanı öldürmekten bir kızla ilk defa birlikte olmaya kadar çeşitli anlamlara sahiptir. Ancak bunların her biri de kitabın temalarını oluşturan yozlaşma, olağan ve güvenli durumun bozulması ve masumiyetin kaybı olgularına dayanır. Yani ister Benk gibi cinsel çağrışımlarla yüklü, ister Yerli gibi masumiyet vurgusu üzerinden giden yaklaşımı tercih edin, kitabın tüm çatısının üzerine kurulu olduğu ana taşıyıcı bu terim ve onu -belki de yanlışlıkla- içeren "Comin' Through the Rye" şiiridir.

Çoşkun Yerli, Ç.N. Dergisinde Gökçe Metin'le yaptığı röportajda romanı önceden tanıdığını, diğer öykülerini okuyunca buna da ulaştığını, ancak ilk başta anlamadığını sözlük aracılığıyla başlangıçta metinle iletişim kurmaya çalıştığını, ardından aldığı notlar sayesinde çeviriyi gerçekleştirdiğini anlatmaktadır.

Çeviri yaklaşımını metni okura ulaştırmak olarak tanımlayan Yerli, erek odaklı bir bakışla metne yaklaştığının ipuçlarını vermektedir; ancak metnin onu zorlamadığını (çünkü kendisi de yatılı okuduğu için Holden'le bağ kurmakta yani metni anlamakta zorlanmadığını) ifade eder. Ancak bu süreçte metinle kültürel bağ kurmakta zorlanmadığını ifade eden Yerli'nin, anlama konusunda sözlük yardımına başvurması ve bu çerçevede çözümler oluşturduğunu söylemesi metinle iletişimin tam gerçekleşmediği kaygısını da beraberinde getiriyor. Yine de çeviri metnin sorunsuz işliyor olması zorlukların aşıldığı duygusunu yaratıyor.

Yerli, Adnan Benk çevirisindeki kitap başlığının, çevirmenin alımlamasına göre uydurulmuş bir başlık olduğunu, "Gönülçelen" kavramının romantik çağrışım yaptığını oysa metnin kapitalist sistemle hesaplaşan, onu eleştiren bir içeriğe sahip olduğundan söz ediyor. Kitabın erotik çağrışımlarının da İskoç Şair Robert Burns'un bir şiirinden esinlenildiğini, bu şiirin, metnin aynı zamanda önemli bir leitmotifi olduğunu da vurguluyor. Bu karşı çıkışına rağmen Yerli de Benk gibi başlık konusunda kaynak metne sadık kalmada sorun yaşıyor. Yukarıda vurguladığımız gibi Yerli "yakalamak" 
sözcüğünden vazgeçiyor. Benk gibi kendi başlığını yaratıyor ya da editör ve yazar bu başlığı uygun görüyor.

Argo kullanımı bağlamında metne yaklaşımında konuşmaların argo içermediğinden ve doğal bir dilin varlığından söz eden Yerli'nin dönemsel bağlamda gençlerin kullandığı dilin argo olarak tanımlamasına katılmasını ilginç bir saptama olarak vurgulamak gerek. Argo hep yaşayan bir dildir ama dönemsel bir gençlik dilinin zaman içinde kaybolup gideceğini gözden uzak tutmaktadır. Bu noktada yaşayacağına inanılan dilin sürdürülmesinden yana tavır almak başkadır, o dilin bir süre sonra yeni kuşakla birlikte kullanım dışı kalacağını düşünmek ayrı bir yaklaşımdır. Burada her ne kadar görünür olma çabasından söz edecek olursak da Yerli, metne bu bağlamda çok müdahil olmamış kendine göre argo olarak tanımlanan cümlelere -kendi ifadesine göre- doğal bir yaklaşımda bulunmuştur. Ayrıca çeviri sürecinde ve sonrasında hem otosansür uygulamadığını hem de yayınevinin böyle bir talebinin olmadığını vurgular (“Coşkun Yerli ile Söyleşi", 2007, s. 10).

\section{2. Çevirmenin Görünmezliği mi Görünebilirliği mi?}

Çevirmenin görünmezliği üzerine tartışırken onun yine de bir biçimde görünebilir olabileceğini de gözden uzak tutmamak gerekir. Çalışmanın başından bu yana bir ergen metnini ele alırken ve ergen metnine dönük çeviri yaklaşımları konusunu araştırırken, aynı zamanda buna karar vermenin zorluklarını ortaya koyduk. Ancak çalışmamız, bir çeviri karşılaştırması olmanın ötesinde çevirmen kararlarının onu nasıl görünmez ya da görünür yaptığını sorgulamayı ve görünmezlik kuramları çerçevesinde ele almanın alt yapısını hazırlamayı önceledi. İnceleme sürecimizde metni sorgulamanın yanı sıra iki çevirmeni ele aldık. Çevirmenlerin kararlarını konuşurken onların bu süreçte görünmezlik bir yana metin ve yazarı kadar görünür olduğunu ve verdikleri kararların onları metnin var oluşuna yaptığı katkıları saptadık. Tüm bunların tartışılır olması çeviribilim açısından baktığınızda bazı konuları salt kuramsal çerçevede değil onu da sorgulayan bir bağlamda ele alınması gerektiği gerçeğine götürdü bizi.

\section{3. Çevirmenin Görünmezliği}

Çeviribilimde 1980 'li ve 1990 'lı yıllarda çeviribilim üzerinde kültürel çalışmaların etkisi giderek artmıştır. Bu gelişme, André Lefevere ve Susan Bassnett'in, Translation, History, and Culture adlı kitaplarında belirttikleri gibi "kültürel dönüş" olarak adlandırılmıştır. Onlara göre bu kültürel dönüş, dilden daha öteye gidilip çeviri ve kültür arasındaki etkileşime, kültürün çeviriyi ne şekillerde sınırlandırdığına ve daha çok bağlam ve tarih gibi kavramlara odaklanılmaya başlanan bir harekettir (Munday, 2001, s. 127). Amerikan çeviribilimci Lawrence Venuti, "çevirmenin görünmezliği” kuramıyla bu kültürel dönüşün önemli bir ismidir.

Venuti, çeviri etiği konusuyla ilgili olarak, Schleiermacher'ın açıkladığı "yazarı okura götürme" yönteminde çevirmenin "görünmez" olduğunu öne sürer. Görünmezlik, çevirmenin dili (burada çevirmenin Türkçeyi) kullanması yolu, yani "söylemin etkisi" ya 
da "çeviriyi okuma veya yorumlama eylemi", yani "çevirinin alımlanması" olmak üzere iki anlama gelebilir (Venuti, 1995, s. 1). Venuti'ye göre, kaynak metindeki yabancı ögelerin kaldırılmasıyla, erek kültürdeki baskın değerlere uygun bir erek metin oluşturulduğunda, metin daha saydam (transparent) ve akıcı (fluent) olmaktadır (1995, s. 21).

Venuti saydamlık ve akıcılığın görünmezlikle ilişkisini şu şekilde belirtir: Saydamlık yanılgısı, akıcı söylemin ve çevirmenin güncel kullanıma bağlı kalarak, devamlı sözdizimi sağlayarak ve belirli bir anlamı sabitleyerek okunurluğu sağlama çabasının bir etkisidir. Burada göze çarpan şey, bu saydamlık yanılgısının etkisinin çevirinin yapılması sırasındaki birçok durumu gizlediğidir. Bu durumların başında da çevirmenin yabancı metne yaptığı müdahale gelmektedir. Çeviri ne kadar akıcıysa, çevirmen o kadar görünmez ve büyük olasılıkla yazar ve yabancı metin de o kadar görünürdür (1995, ss. 12).

Venuti'nin "yerlileştirme" ve "yabancılaştırma" kavramları da ilk kez The Translator's Invisibility: A History of Translation (1995) adlı kitabında yer almıştır. Venuti, Schleiermacher ile başlayan "okuru yazara götürme" veya "yazarı okura götürme" yöntemlerinden yola çıkarak "yerlileştirme" ve "yabancılaştırma" stratejilerini öne sürmüştür. Buna göre "yerlileştirme", "yabancı metnin, erek dilin kültürel değerlerine indirgenmesi" olarak tanımlanırken, ikinci yöntem olan "yabancılaştırma", "erek dilin kültürel değerlerinin, kaynak dilin dilsel ve kültürel farklılıklarını aktarması" olarak tanımlanmıştır (Venuti, 1995, s. 20).

Yerlileştirme yöntemi, kültürler arası farkları saklama amacı taşındığında uygun bir yöntemdir. Venuti, Anglo Sakson kültürünü başarılı bir şekilde diğer ülkelere empoze eden İngiltere ve Amerika'nın, buna karşılık İngiliz ve Amerikan yayıncılı̆̆ında yerlileştirme stratejisinin kullanılmasının finansal olarak da ülkelerin yararına olduğundan söz eder. Kendi içlerinde tek dilli, yabancıyı kabul etmeyen ve okurların okudukları eserlerde kendi kültürlerini görmelerini sağlayan yerlileştirilmiş çeviri metin, okunurluğu arttırdığından ve daha kolay tüketilebildiğinden, yayıncılar, editörler ve eleştirmenler tarafından tercih edilmektedir (Venuti, 1995, ss. 15-6). Kısacası "yerlileştirme", güçlü ve baskın ülkelerin, dış kültürleri kendi içlerine almalarına izin vermeden, okuyucuya sadece aşina oldukları kültürü sunmaya devam etmelerine yardımcı olan bir yöntemdir.

Bunun yanında Venuti, yabancının "yabancılığının” da aslında sadece erek dilin kültüründe tanımlanabildiğinden ve sadece yerel değerlerle karşılaştırıldığında "yabancı" olduğuna karar verilebildiğinden söz eder. Bu görüş dikkate alındığında, "yabancılık" kavramı, erek kültürdeki güç dengelerine göre belirlenir. Bu yüzden Venuti, çevirinin her zaman yerelleştirme içerdiğini belirtir. Yani yerelleştirme kaçınılmazdır. Ancak bu yöntem, asimilasyon şeklinde gerçekleşmemeli, yani yabancı metin baskın erek kültür değerlerine indirgenmemelidir (Venuti, 1995, s. 203). 
Dolayısıyla Venuti, kavramlarını fikirlerine dayandırdığı Schleiermacher ile aynı fikirdedir. Çevirmen, Schleiermacher’ın ikinci yöntemini, yani "yabancılaştırma" yöntemini benimsemelidir. Ancak bu yöntemin tercih edilmesinin ardındaki nedenler söz konusu olduğunda Schleiermacher ile görüşleri uyuşmaz. Venuti, yerlileştirmenin şeffaflık yanılgısı yarattığını ve bu şekilde akıcılık sağladığını belirtirken, yabancılaştırmanın "etnosentrizme, ırkçılığa, kültürel narsizme ve emperyalizme karşı bir tür direniş" olduğunu belirtir (Venuti, 1995, ss. 20-1). Çevirmeni yabancı metinlerin kültürel ve dilsel farklılıklarını ayırt edecek şekilde çevirmeye, okuru da çeviri metni bu şekilde okumaya çağırır (Venuti, 1995 s. 41). Venuti, çevirmenin görünürlüğünün öneminin ve yabancılaştırma ile ilişkisinin altını şu şekilde çizer: "Çevirmenin görünmezliğinin farkına varmak; mevcut durumu eleştirmek ve çevirmenin ele alacağı farklılıklara karşı daha ılımlı bir geleceği ümit etmek demektir" $(1995$, s. 313).

Yabancılaştırma konusunda, baskın olan, güçlü dile karşı yapılan direnişten söz edilirken, bahsedilen sadece İngilizcenin diğer dillere karşı olan hegemonyası değildir. Venuti ayrıca, bir dil içinde standart ile azınlık dilleri arasındaki ilişkiden de söz eder. İyi bir çevirinin özelliği olarak ortaya attığı "minoritizing" kavramı, bu azınlık dillerinin de özelliklerinin saklanmaması, ortaya çıkarılması anlamına gelmektedir. İyi bir çeviri, heterojendir; kaynak metin unsurları iyi bir çeviri metinde aynen tutulur. Standart lehçenin ve edebi kanonun onlara yabancı olana, standardın altında olana, marjinal olana açılması gerekir. Böylece çevirinin asimile edici özelliği engellenmiş olur (Venuti, 1998, s. 11).

Çeviribilim alanında Venuti'nin ortaya attığı bu görüşleri eleştiren görüşler de yok değildir. Öncelikle, "yerlileştirme" ve "yabancılaştırma" kavramları zıt iki noktayı seçme gerekliliği olarak görüldüğünden, eleştirilere neden olmuştur. Anthony Pym ve Maria Tymoczko bu kuramcılar arasındadır. Pym, bu iki zıt yöntemin bir aracı olan çevirmeni baskı altına aldığını öne sürer. Ona göre, Schleiermacher'in metninin tamamı, "çevirmeni susturmak üzerine tasarlanmıştır" (Pym, 1995, s. 5). Ona göre çeviribilimde ikicilik olan birçok kuramın yaptığı da çevirmenin ve çevirmenin yerinin geçerliliğini reddetmektir. Maria Tymoczko da iki yöntem arasındaki bu kesin tercih yapma gerekliliğine karşı çıkar. Tymoczko'ya göre çeviri, sanki bir düzlemdeki doğrunun tek bir yönünü seçermiş gibi tek bir uç seçilerek yapılamaz. Çevirmen, yeri geldiğinde bu iki ucun ikisinde de aynı anda durabilir (1999, s. 56).

Venuti, kendine karşı yapılan eleştirilere The Translator's Invisibility kitabının 2008 yılında çıkan yeni basımının ön sözünde cevap vermiştir. Venuti'ye göre "yabancılaştırma" ve "yerlileştirme" kavramları, birbirine zıt iki noktada değildir; bu kavramlar yabancı bir metne karşı benimsenen etik duruşu yansıtır. Bu etik duruş, hem çevrilecek metin seçimi hem de metin içi çeviri yöntemleri ile belirlenebilir (Venuti, 2008, s. 19). Bir başka deyişle, bu yöntemler çeviri eylemine başlamadan önce çevirmenin zıt kutuplardan birini tercih ederek ona göre hareket etmesini gerektirmez. 
Venuti'nin yabancılaştırma yönteminin bir tür direniş olması fikri de Pym tarafından eleştirilir. Venuti'nin egemen kültüre ait dilin yabancılaştırma yöntemi kullanılarak güçsüzleştirilmesi fikri, her dil için geçerli olmak zorunda değildir. İki yöntem arasında çevirmenin tercih yapması gerekliliğini eleştiren Pym'in aynı zamanda Venuti sayesinde kuralcı anlayıştan uzaklaşılarak çevirmenin nasıl çevirmesi gerektiğinin konuşulmaya başlandığını da belirtmesi dikkate değerdir. Pym'e göre Venuti sayesinde çevirmenlerden siyasi durumların içindeki gerçek insanlar olarak bahsedilmeye başlanmıştır (1996, s. 176). Pym ayrıca Venuti'nin çevirmenlerin ve gelecek toplumların birbiriyle ilişki kurabilmesini sağlayan etik faktörlerden konuşulmasını da sağladığına değinir.

Venuti, kullandığı terimlerin tam ve açık birer tanımının olmaması konusunda da eleştirilmiştir. Tymoczko, Venuti'nin bir yerde yabancılaştırmayı metin içindeki stratejilerle anlatırken, başka bir yerde metnin akıcılığının ancak metin seçiminde yabancılaştırmaya gidilmesi halinde mümkün olduğunu söylemesinin sorun teşkil ettiğini savunur (2000, s. 36).

Buna karşın Venuti, yabancılaştırma yöntemini izlemenin akıcılıktan tamamen uzaklaşmak anlamına gelmediğini belirtir. Akıcılıkla ne anlaşıldığının zamandan zamana ve kültürden kültüre değişiklik gösterdiğini söyleyen Venuti’ye göre çevirmen akıcı olmak için yeni yöntemler bulabilir ve hem yabancılaştırma yöntemini kullanıp hem de akıcı olmaya çalışması çeviri yaptığı dildeki kaynakları kullanmasına bağlıdır (Venuti, 2008, s. 19). Yani Venuti'ye göre yabancılaştırma ve yerlileştirme birbirinin tam zıttı uçlar olmadıkları gibi, akıcılıktan uzaklaşmak yabancılaştırmadan uzaklaşmak anlamına da gelmek zorunda değildir.

Jeremy Munday'e göre, Venuti çevirilerin analiz edilmesi için özel bir yöntembilim sunmamıştır. Kullanılan çeviri yöntemlerini değerlendirmek için çeşitli çevirmen ön sözlerini, kaynak ve erek metinlerden alınan parçaları incelemiştir. Bunun yanında, Munday, Venuti'nin yabancılaştırma, yerlileştirme ve çevirmenin görünmezliği konusundaki genel dayanaklarını şu şekilde sıralar: yerlileştirme ve yabancılaştırma işaretleri için erek ve kaynak metnin dilsel olarak incelenmesi, çevirmenler, editörler, yayıncılarla yapılan röportajlar, varsa çevirilerin taslaklarının incelenmesi, kaç kitabın çevrildiği ve satıldığına bakılması, rakamların zaman içinde ne şekilde değiştiği, çeviri için yapılan anlaşmalara ve nihai üründe çevirmenin ne kadar "görünür" olduğuna bakılması, metnin yapısına, başlık sayfasına, kitap kapağına, çevirmen ön sözüne bakarak çevirmenin ne kadar görünür olduğunun incelenmesi (Munday, 2001, ss. 155-6).

Çevirmenin görünür olmasının gerekliliğinin çeviribilim çalışmalarında en yaygın olarak kabul gören görüş olduğunu savunan Kaisa Koskinen, görünürlük kavramının detaylandırılması gerektiğini savunur (Koskinen, 2000, ss. 98-9). Ona göre, üç tür çevirmen görünürlüğü vardır: metin içi, metin ötesi ve metin dışı görünürlük. Metin içi görünürlük söz konusu olduğunda, çevirmen çeviri metin içinde kendi varlığını görünür kılar. Venuti'nin de savunduğu bu tür görünürlük, aslında çeviride kaçınılmaz olarak 
vardır. Metin ötesi görünürlük, çevirmenin çevirisi hakkında metin sınırları içinde veya dışında yorum ve incelemeler yapmasıdır. Metnin çeviri olduğuna dair bir işaret, örneğin metne çevirmenin imzasının eklenmesi ya da çevirmenin ön sözü veya son sözü bu görünürlük türüne örnek olarak gösterilebilir. Son olarak, çevirmenin dışında çeviriyle ilgili olan kişiler tarafından çevirmenden de bahsedilen yorumlar, metin dışı görünürlük sınıflandırması içindedir. Bir eserin yayıncısının, eseri tanıtırken çevirmenden bahsetmesi veya bir gazetede veya dergide eserin yorumlanırken çevirisinin de yorumlanması bu türe örnek olarak gösterilebilir.

Koskinen'in söylediklerinden yola çıkarsak çevirmenin görünürlüğünün gerekliliği üç başıkta ele alınır: metin içi, metin ötesi ve metin dışı. Her iki çevirmenin yaptıklarını değerlendirirsek, metin içi çerçevede çevirinin yapıldığı kaynak metinler onların kararlarını etkilemiş ve görünür kılmıştır. Benk, Fransızca kaynak metni kullanmış ve o dilde yapılan müdahaleleri daha bir öne çıkarmış, aynı zamanda güçlü bir çevirmen olarak bilinen Benk'in metne karşı daha bir iktidar olarak durduğu gerçeğini ortaya koymuştur. Yerli ise metni hedef kitlesine götürmek isteğini vurgularken anlaşılır kılma kaygısıyla metne farklı yaklaşmıştır. Bu da onun görünürlüğünü artırmıştır.

Venuti'ye göre bakarsak kısaca söylemek gerekirse kitapların her iki çevirmenin metinlerinden sorunsuz okunması onların okuma sürecinde görünürlüğünü yok etmiş ama sonrasında bu görünmezlik, çeviri metnin saygınlığı çerçevesinde görünürlüğe dönüşmüştür.

\section{Sonuç}

Kitap, bir ergen romanı olarak yayınlandığı dönemi ve ülkesini (Amerika) etkilediği gibi çeviri yoluyla tüm dünyaya ve genç, yaşı okurlara ulaşmış ve onlarda da unutulmaz etkiler yaratmıştır. Dönemine bakıldığında ideal mükemmel çocuk anlayışı gereğince yatılı okula iyi bir eğitim alması için gönderilen Holden, okul hayatında ve dış dünyada asla uyum sağlayamayacağı insanlarla karşılaşır. Ergenliğin zirve noktasında dolaşan Holden'in bu uyumsuzluğunu anlatmaya çalışan yazar aynı zamanda ergenin muhalif ruhunu da kullanarak dönemimin anlayışlarıyla ciddi biçimde hesaplaşır. Yaşadığı dünyayı sahteliklerle kaplı bir dünya olarak algılayan Holden bu uyumsuzluğunu farklı deneyimlerle aşmaya ya da bunu anlayıp aşmaya çalışır ama her seferinde daha da derine gömülür. Holden'in en temel sorunu kendisine dayatılan yetişkinler dünyasına girmeyi reddetmesidir. Yetişkinler dünyası bunu olgunlaşma olarak tanımlarken Holden bunu kendinden vazgeçmek olarak tanımlar. Masumiyetin sembolü olarak gördüğü kız kardeşi Phobe'ye anlattığı "çavdarın avcısı" olma fantezisi onun yaşamı algılayışının ipuçlarını verir. Çocukların hayali bir uçurumdan ölüme ya da yetişkinliğe düşme durumunda kalan çocukları yakalayıp kurtaran olacaktır.

Ama küçük kardeş onun uyumsuzluğunu saptamış ve onu uyarmıştır. Holden yetişkinliği erteleyerek yaşamdan uzak kalmaya çalışır ve bu bir ergenin dönemsel bağlamda yaşayacağı en önemli ve engellenemez kaçışıdır. 
Kitap tüm bunları öne çıkararak aslında ergen sorunlarına, onun başkaldırıları aracılığı ile dönemin eğitim anlayışına, aile ilişkilerine çok önemli eleştiriler getirir. Türkiye'deki alımlamasına baktığımızda kitap, okul sistemine dahil olmamış ama yine de ciddi sayıda okura ulaşmıştır.

Çeviri yaklaşımları açısından baktığımızda yayınlandığı zaman kendi ülkesinde yasaklanan bu kitap, belki de olumlu yaklaşılmasını sağlamak için diliçi çeviriye ihtiyaç duymuş olabilir, çünkü ergenliğin bir dönem olarak algılanması ve kabul görmesi oldukça zor olmuştur. Bu nedenle farklı dünya dillerine çevrilirken çevirmen kararları her ne kadar başka bir araştırma konusu olsa da dilimize yapılmış iki çevirinin bile çevirmenin görünürlüğü ya da görünmezliği ve çevirmen kararları açısından oldukça tartışma yaratmış olsa da metnin gücünün çevirmen kararlarını çoktan aştığını; alımlamanın çok da fazla değişmediğini görmek mümkündür, çünkü iki başlık da yabancılaştırıcı unsurlar taşımaktadır. Ancak iki başlık ve metnin içinde var olan dönemsel gençlik dilinin (argo değil) doğru algılanmadığını söylemek mümkündür. Bütün bunların neden metnin okunurluğunu ve okura ulaşıp iletişim kurmasını engellemediğini görmek, onun klasikleşmiş bir popüler metin olmasından mı, yoksa derin sosyopsikolojik anlamından mı kaynaklandığı sorularını beraberinde getiriyor, bunu da metin psikolojisi ve çeviri psikolojisi bağlamında ayrıca incelemek gerek. Ancak kültürel eşdeğerlilik açısından baktığımızda aynı olmasa da gençliğin benzer sorunlarla boğuştuğu ve bunun edebiyata yansıdığını görüyoruz. Salinger'in bu metninin -ikinci dilden bile olsa- Benk tarafından çevrilmesi öncü bir tavırdır ve metnin kültürel bağlamda bizim edebiyat dizgemize girmesini sağlamıştır. Yerli ise kaynak metinden yola çıkarak çevirisini yapmış ancak erek odaklı diyebileceğimiz bir tavırla metne yaklaşmış onu okura taşımaya çalışmış ama yine de metnin temsil ettiği kültür dilini (gençlik dili) aktarma konusunda çekingen kalmıştır.

Tüm bunlar, çevirmenlerin görünürlüklerini sağlamış, her iki çevirmen yeni bir edebiyat örneğini çevirirken kendilerine özgü kararlar vermek zorunda kalmışlardır.

\section{Kaynakça}

Asutay, H. (2001). Gençliğin Dili. Dokuz Eylül Üniversitesi Sosyal Bilimler Enstitüsü Dergisi, 3(2), 121.

Baacke, D. (1987). Jugend und Jugendkulturen. Weinheim/München: Darstellung und Deutung.

Barthes, R. (2016). S/Z (Çev. S. Öztürk Kasar). İstanbul: Sel Yayıncılık.

Coşkun Yerli ile Söyleşi. (2007) Ç.N. Çevirmenin Notu Dergisi, 4. Erişim: http://cevirmeninnotu.blogspot.com/2007/10/cokun-yerli-ile-sylei.html

Hermans, T. (2003). Translation, equivalence and intertextuality, Wasafiri, 18(40), 39-41.

Hermans, T. (2007). Translation, irritation and resonance. M. Wolf \& A. Fukari (Eds.), Constructing a Sociology of Translation (ss. 57-75). Amsterdam: John Benjamins. 
Koskinen, K. (2000). Beyond ambivalence: Postmodernity and the ethics of translation. Tampere: Tampere University Press.

Kesey, K. (1962). One Flew Over the Cuckoo's Nest. New York: Viking Press \& Signet Books.

Lefevere, A. (1977). TranslatinglLiterature: The German tradition from Luther to Rosenzweig. Assen ve Amsterdam: Van Gorcum.

Lefevere, A. (1992). Translation, rewriting, and the manipulation of literary fame. Londra ve New York: Routledge.

Munday, J. (2001). Introducing translation studies: Theories and applications. Londra: Routledge.

Munday, J. (2009). The Routledge companion to translation studies. Londra ve New York: Routledge.

Pym, A. (1995). Schleiermacher and the problem of blendlinge. Translation and Literature, 4(1), 530.

Salinger, J. D. ( 1995). Gönülçelen (Çev. A. Benk). Can Yayınları: İstanbul.

Salinger, J. D. (2006). Çavdar Tarlasında Çocuklar (C. Yerli, Çev.). YKY: İstanbul.

Tymoczko, M. (1999). Translation in a postcolonial context: Early Irish literature in English translation. New York: Routledge.

Venuti, L. (1991). Genealogies of translation theory: Schleiermacher. TTR: Traduction, Terminologie, Rédaction, 4(2), 125-150.

Venuti, L. (1995). Translator's invisibility: A history of translation. Londra ve New York: Routledge.

Venuti, L. (1998). The scandals of translation: Towards an ethics of difference. Londra ve New York: Routledge.

Venuti, L. (Ed.). (2000). The translation studies reader. Londra ve New York, Routledge.

Venuti, L. (2008). Translator's invisibility: A history of translation. Londra ve New York: Routledge. 